\title{
Review of Ontology and economics: Tony Lawson and his critics, edited by Edward Fullbrook. Oxford (UK): Routledge, 2009, 384pp.
}

\author{
DUNCAN HODGE \\ University of South Africa
}

The mid-1990s saw the methodology of economics increasingly turn away from epistemological issues as developed by Popper, Kuhn and Lakatos with regard to the natural sciences. Philosophy of economics was by then moving in refreshingly new directions in a spirit of reflection and re-evaluation which helped dispel the stale air of the old rules and criteria bound methodological debates. One of these new projects was a re-awakening of philosophical interest in the basic nature of the subject matter of the social world, and the related questions of how economists theorize about it and whether or not the methodology of economics was appropriate to its subject. This new project put ontological realism at the foreground of research in the philosophy of economics.

Despite sharing a common concern with ontological issues, at an early stage the project split into two distinct programs headed up by Tony Lawson and Uskali Mäki respectively. Mäki pursued a more neutral program of conceptual analysis and clarification to examine how and why economists theorize in the way that they do, such as their commonplace acceptance and use of false theoretical assumptions, without directly criticizing or offering methodological advice. By contrast, Tony Lawson subjects what he regards as the mathematicaldeductivist methodology of mainstream economics to a comprehensive and radical re-evaluation informed by the ontological presuppositions of critical realism. The insights of critical realists such as Roy Bhaskar are familiar to academics in other social sciences such as sociology, but as applied by Lawson it has given economists something of a wake-up call regarding their often taken for granted ontological and methodological presuppositions.

Tony Lawson's critique of mainstream economics was set out systematically in his Economics and reality (1997). This was followed by Reorienting economics (2003) which tries to establish common ground 
with heterodox thinking in economics and other social sciences and encourages a fundamental change of perspective in the methodology of the mainstream. The ten contributors to Edward Fullbrook's volume all apparently agree with Lawson on at least some of the basic ontological and realist issues (not necessarily the same ones) examined in these two books, but are unhappy with various other aspects of his critique and suggested reorienting of the mainstream.

The ten contributors to the volume, introduced alphabetically in the book in order not to create the impression that any particular critic is more important than another (with their central concerns in parentheses) are: Bruce Caldwell (defends the usefulness of "basic economic reasoning" by mainstream economics); Bjørn-Ivar Davidsen (questions the philosophical underlabouring role of critical realism as a precursor to or substitute for more substantive scientific theorizing and more concrete empirical application); John B. Davis (questions Lawson's characterization of heterodox economics and the criteria used for differentiating it from orthodox economics); Paul Downward and Andrew Mearman (Lawson's critique fails to give much practical guidance to research in economics, which can be remedied by adopting their principle of triangulation); Bernard Guerrien (the choice of grossly distorted assumptions about households and firms used in formal economic model-building is conditioned by ideological preferences that are impervious to the arguments of ontologists); Geoffrey M. Hodgson (given that strict local closures and event regularities are rare in open economic systems, Lawson's critique of formalism in economics is too limiting in arguing that the mathematical-deductivist method which requires such event regularities is inappropriate and likely to fail); Bruce R. McFarling (epistemology may be more successful than ontology in showing how and why mainstream economics should be reoriented); David F. Ruccio (argues that Marxism and postmodernism are powerful alternatives to the critical realist critique of the mainstream and suggests that no single ontological theory is likely to unify the different heterodox approaches in this regard); Irene van Staveren (contests aspects of Lawson's support for feminist issues in economics and notes that his anti-formalist position may stymie feminists wanting to explore such issues using formal modelling techniques); Jack Vromen (argues that Lawson's confidence in the ontological presuppositions of critical realism and analysis of deficiencies in mainstream economics is misplaced, suggesting that we should rather regard critical realism as an 
example of "conjectural revisionary ontology" which could be used heuristically to develop more substantive theoretical and empirical research alternatives to the mainstream).

In answering these criticisms, Lawson uses the opportunity to further clarify and develop his own ideas about what he regards as the formal model-building and econometric methodological approach of the mainstream, and the possible alternatives to it grounded on the ontological insights of critical realism. All his rejoinders are considerably longer than the contributions themselves (his reply to Hodgson's thirteen-page piece on formalism in economics takes up all of forty-two pages including an addendum and notes) and are the result of long and careful deliberations in fashioning his counterarguments. In his introduction, Fullbrook comments that Lawson waited until he had completed all ten of his rejoinders before submitting any of them and responding to his critics. Whether or not one is persuaded by Lawson's answers it is nevertheless a compelling tour de force that is at the cutting edge of thinking in this area of the philosophy of economics.

Because his critics cover diverse issues and Lawson's response to them is so detailed, it is difficult to give an adequate appraisal thereof in this short review. I will focus on just a few fundamental issues that seem to tap into the broader conversation. In his introduction, Fullbrook outlines Lawson's ontological ideas according to the five basic properties of social phenomena embraced by critical realism: they are produced in open systems; they possess emergent powers or properties; they are structured; they are internally related and; they are processual. As explained by Fullbrook, these properties are not in any way unique to Lawson's ontological critique of economics. They are part of established critical realist social theory in general as developed by Bhaskar and others in the 1970s. Moreover, these ideas were already commonplace in continental philosophy and literature well before the advent of critical realism (Fullbrook refers to the writings of Simone de Beauvoir as an example thereof). According to Fullbrook, these ideas and the social theories derived from them are so well established and legitimized outside of mainstream economics that "no one of repute" has dared to challenge Lawson that the economy is indeed characterized in this way and: "Only a fool would publicly take up these arguments" (pp. 6-7). However, at least three of the contributors to the volume appear to risk making fools of themselves along these lines. 
Davidsen argues that because critical realists shy away from more substantive economic theorizing and concrete empirical analysis, much of the explanatory work is done by their ontological account of social reality. Davidsen then suggests that the critical realist account in terms of the five properties believed to apply to all social phenomena is just one of many possible ontological theories in this regard. In other words, no matter how seemingly well-established, obvious, appropriate, and legitimate the critical realist ontological account is it is nevertheless a fallible theory. (In his rejoinder, Lawson points out that he has always regarded his critical realist account as such, even though he regards it as the best grounded compared to any alternative ontological conception or theory he has come across to date. Moreover, the general critical realist account can inform different and competing substantive economic theories and empirical analysis. Thus, argues Lawson, it is strategically unhelpful to point to more specific theories or illustrations of critical realism at work since it might be mistakenly inferred that the rejection of any such individual theory undermines the whole critical realist account).

Later, Ruccio argues that Marxian and postmodernist theories are good examples of alternative ontological conceptions of social reality which can provide their own penetrating insights and critique of mainstream economics. Ruccio points to the Marxist/postmodernist notion of a dialectical interaction between theory and the construction of multiple social realities which he argues is incommensurable both with the mainstream and with the heterodox theories that Lawson suggests have common ontological ground with critical realism. (Lawson answers that given this common ground-see also his response to Davis's criticisms in chapter six-it is hard to argue that different heterodox theories, including the Marxist and postmodernist ontological theories preferred by Ruccio, are incommensurable. Even the mainstream orthodoxy-Lawson suggests-is not incommensurable in the sense of being unable to evaluate its respective worth in explaining social reality).

And Jack Vromen takes Lawson to task for asserting that the critical realist transcendental mode of inference, although fallible, is the best available approach to explaining social phenomena, and suggests that it rather serve as an alternative "conjectural revisionary ontology" which, echoing Davidsen, should be used to develop more substantive 
theoretical and applied research in this regard (Lawson's response here is similar to his rejoinder to Davidsen).

Despite the diverse criticisms of the contributors and Lawson's thorough responses to them, a basic issue that I suspect many will still find unsatisfactory is Lawson's characterization and appraisal of mainstream economics. To summarize briefly, it is characterized by Lawson as the dogmatic insistence on the two methodological ugly sisters of mathematical-deductivist model-building and the econometric estimation of the formal models so constructed. Such an approach, argues Lawson, is likely to fail because it entertains a fundamentally mistaken ontological conception of economic and social reality. This reality, with few exceptions, does not contain the local closures and atomistic units of analysis necessary for the event regularities upon which the success of the project inescapably depends. According to Lawson, the signs of failure are endemic to the mainstream and are selfevident to both those working in heterodox alternatives and to important theorists within the mainstream itself.

Is the mainstream adequately defined and characterized as the dogmatic insistence on formal mathematical model-building and econometrics, leading to endemic explanatory and predictive failure? In his introduction, Fullbrook quotes Nobel prize-winners Milton Friedman (1999) and Ronald Coase (1999) who both criticize economics for being preoccupied with mathematical technique and method divorced from economic reality. This is also Mark Blaug's (1997) complaint about modern economics which elsewhere he traces back to the formalist revolution in the 1950s (Blaug 1999; 2003). Both Lawson and his critics appear to agree in this respect at least. Now both Friedman and Coase were highly influential economists, in macroeconomics and micro-economics respectively, neither of whom, it may be argued, indulged in formal mathematical model-building. The kinds of theorizing and empirical work they were engaged with are very different to the more formal mathematical theory and model-building of, say, the new classical economists or the game theorists in microeconomics. Should Friedman and Coase be defined as non-mainstream economists because they did not make use of formal mathematical analysis?

Perhaps Lawson would argue that although they used less formal approaches in developing their explanatory theories, their mode of reasoning is still based on the mathematical-deductivist method. 
But then Lawson would surely have to admit that mainstream economics thus defined is capable of producing significant and successful explanatory theories (which of course allows that they are contestable and may be superseded by alternative theories). Thus, Friedman's adaptive expectations critique of the Phillips curve trade-off was regarded as a good explanation of stagflation during the 1970s and had major implications for the role and conduct of monetary policy which in some respects are still recognized today. And, despite being treated by some Institutionalists as their adopted son, Coase's theory of transactions and social costs, externalities, efficiency, and the allocation of property rights is surely also an example of a highly successful explanatory theory in mainstream economics which does not involve any formal mathematics or econometrics.

More generally, mainstream economics appears capable of entertaining two different streams in terms of method, with less formal approaches and quantitative methods (e.g., Smith, Marshall, Keynes, Kuznets, Friedman, Coase) flowing alongside the more mathematically formalized approaches (e.g., Ricardo, Walras, Samuelson, Nash, Arrow, Debreu, Lucas). My point here is simply to question the idea that mainstream economics can be equated with the methodologically dogmatic insistence on formal mathematical model-building and econometrics. Both its history and current state suggest that it is a broad church able to accommodate a range of less formal models, quantitative techniques and empirical analysis (involving, perhaps, the "basic economic reasoning" that Caldwell tries to articulate in his contribution) alongside the more formalized approach.

At the end of his piece defending what he regards as the acceptable use of formal methods in economics, Hodgson notes in support of his argument that sociology, which makes little use of formal mathematics in its explanatory theories, is itself "widely acknowledged to be in a state of severe disorder, especially concerning its core presuppositions, its self-identity and boundaries, and its relations with other disciplines, particularly economics and biology" (p. 186). Hodgson concludes that formalism can thus be only part of a much broader malady afflicting the social sciences generally. In his forty-two page reply to Hodgson, Lawson remains uncharacteristically silent on this issue. Perhaps Hodgson's perceptive observation can also be used to make a related point: that there is an academic specialization and division of labour in studying the social world with each of the related 
but separate disciplines cleaving to their own preferred methodological approach. Thus the economist, sociologist, economic historian, political scientist, and business school academic have their own distinctive (possibly partially overlapping and also contestable) methodologies, leading to a splendid variety of more substantive theories and models of social and economic reality, each with their individual strengths and weaknesses, successes and failures. It thus appears to me that Lawson's critical realist case for finding a common ground between heterodox approaches and enlisting help to try to reorient the "failed" mainstream economics project is not likely in the end to meet with much more than the limited success it has experienced to date.

\section{REFERENCES}

Blaug, Mark. 1997. Ugly currents in modern economics. Options Politiques, 18 (17): 3-8.

Blaug, Mark. 1999. The formalist revolution or what happened to orthodox economics after World War II. In From classical economics to the theory of the firm: essays in honour of D. P. O'Brien, eds. R. E. Backhouse, and J. Creedy. Cheltenham: Edward Elgar, 257-280.

Blaug, Mark. 2003. The formalist revolution of the 1950s. In A companion to the history of economic thought, eds. W. J. Samuels, J. E. Biddle, and J. B. Davis. Malden (MA) and Oxford (UK): Blackwell, 395-410.

Coase, Ronald. 1999. An interview with Ronald Coase. Newsletter of the International Society for New Institutional Economics, 2 (1): 3-10.

Friedman, Milton. 1999. Conversation with Milton Friedman. In Conversations with leading economists: interpreting modern macroeconomics, eds. B. Snowdon, and H.

R. Vane. Cheltenham: Edward Elgar, 124-144.

Lawson, Tony. 1997. Economics and reality. London: Routledge.

Lawson, Tony. 2003. Reorienting economics. London: Routledge.

Duncan Hodge is professor of economics at the University of South Africa. His main research interests are divided between philosophy of economics, focussing on the areas of ontology, realism/realisticness, and the different ways in which models are used in economics; and applied macroeconomics, with a particular focus on the South African economy.

Contact e-mail: <hodged@unisa.ac.za> 